Original Research Paper

\title{
Dynamics of Mechanisms with Cams Illustrated in the Classical Distribution
}

\author{
${ }^{1}$ Relly Victoria Virgil Petrescu, ${ }^{2}$ Raffaella Aversa, ${ }^{3}$ Bilal Akash, \\ ${ }^{4}$ Ronald Bucinell, ${ }^{5}$ Juan Corchado, ${ }^{6}$ Samuel P. Kozaitis, \\ ${ }^{7}$ Taher M. Abu-Lebdeh, ${ }^{2}$ Antonio Apicella and ${ }^{1}$ Florian Ion Tiberiu Petrescu \\ ${ }^{1}$ ARoTMM-IFToMM, Bucharest Polytechnic University, Bucharest, (CE), Romania \\ ${ }^{2}$ Advanced Material Lab, Department of Architecture and Industrial Design, \\ Second University of Naples, 81031 Aversa (CE), Italy \\ ${ }^{3}$ Dean of School of Graduate Studies and Research, American University of Ras Al Khaimah, UAE \\ ${ }^{4}$ Union College, USA \\ ${ }^{5}$ University of Salamanca, Spain \\ ${ }^{6}$ Florida Institute of Technology, USA \\ ${ }^{7}$ North Carolina A and T State University, USA
}

Article history
Received: 25-05-2017
Revised: 29-05-2017
Accepted: 05-06-2017
Corresponding Author:
Florian Ion Tiberiu Petrescu
ARoTMM-IFToMM,
Bucharest Polytechnic
University, Bucharest, (CE),
Romania
Email: scipub02@gmail.com

\begin{abstract}
The paper presents an original method to determine the general dynamics of rotating cam and lifting, customized to flat-plate mechanism. First, the dynamic cinematic is presented. Then the Lagrange equation is resolved and with an original dynamic model with a degree of freedom with variable internal damping the dynamic analysis of two models is then made. The mechanisms presented, scientifically called rigid memory mechanisms, are mechanical transmissions widely used in the economy for many years. They are widespread in the medical world, being used in various medical devices and in medical engineering, they also meet most of the vehicles mounted on their engines, with internal combustion, as valve distribution mechanisms, in the world of industrial robots, but also in the Of mechanical transmissions. The cam and follower mechanisms have spread the first time they were used in the wars of tissue (automated tissue machines). The distribution mechanisms could not be replaced with other electromechanical systems because they did not have the necessary resistance and reliability.
\end{abstract}

Keywords: Cam, Cams, Rotating Cam, Follower, Lifting Mechanism, Tappet, Valve Distribution Mechanisms, Lagrange Equation, Degree of Freedom, Dynamic, Cinematic, Dynamic Cinematic, Automation, Engines, Thermal Engines, Medical Devices, Industrial Robots, Mechanical Transmissions

\section{Introduction}

The development and diversification of machines and mechanisms with applications in all fields requires new scientific researches for the systematization and improvement of existing mechanical systems by creating new mechanisms adapted to modern requirements, which involve increasingly complex topological structures.

The modern industry, the practice of designing and building machinery is increasingly based on the results of scientific and applied research.
Each industrial achievement has backed theoretical and experimental computer-assisted research, which solves increasingly complex problems with advanced computing programs using increasingly specialized software.

The robotization of technological processes determines and influences the emergence of new industries, applications under special environmental conditions, the approach of new types of technological operations, manipulation of objects in the alien space, teleoperators in the top disciplines like medicine, robots 
covering a whole field greater service provision in our modern, computerized society.

In this context, the present paper attempts to make a scientific and technical contribution to the dynamic analysis and synthesis of the camshafts and planetary gears (Mirsayar et al., 2017).

The oldest pharmacy in history dates from 754. It was opened in Baghdad by Arab pharmacists, under the Abbasid caliphate, the sayadilas and was soon joined by others, initially in the medieval Islamic world and, In Europe.

In the nineteenth century, many European and North American pharmacies became full-fledged pharmaceutical companies and in fact most of the current pharmaceutical companies were founded at that time.

In the twentieth century, the central discoveries of the 1920 s and 1930s in the field of medicine, such as penicillin and insulin, began to be produced in industrial quantities and distributed to retail. Switzerland, Germany and Italy have particularly strong industries, closely followed by the United Kingdom, the United States, Belgium and the Netherlands.

Legislation is adopted to frame experiments and approve medicines that receive an appropriate label. The distinction is made between prescription drugs and over-the-counter drugs as the pharmaceutical industry grows and matures.

The pharmaceutical industry is developing seriously since the 1950s, following the development of a systematic and scientific approach, a better understanding of the human body (in particular with DNA) and the emergence of more sophisticated.

During the $1950 \mathrm{~s}$, several new medicines were developed and were distributed in large quantities in the 1960s. Among these are the first form of oral contraception, "the Pill", Cortisone as well as medications for the control of blood pressure and for other heart diseases. The field of drugs for psychiatric and depressive illnesses is also developing. Valium (diazepam) was discovered in 1960 and began to be prescribed in 1963, becoming the most prescribed drug in the history of pharmacy.

To govern the development of pharmaceutical companies, governments are undertaking numerous legislative measures. In the United States, the Food and Drug Administration (FDA), founded in 1906, is one of the first state institutions to provide legal oversight for a market that was previously free. It was subsequently placed under the authority of the Ministry of Health, Education and Welfare from 1953. In France, it was not until 1993 that the "Agence du médicament" (now the ANSM).

In 1964 the World Medical Association published the Helsinki Declaration, which stipulates certain rules of clinical research and requires a subject to give explicit authorization before it can be used in clinical trials for new drugs. Pharmaceutical companies are then asked to prove the effectiveness of the medical tests before authorizing the sale of a new drug.

Until the 1970s, this industry remained relatively circumscribed despite strong growth potential. In the context of globalization and competition it has exacerbated, a race for patent filings (which protect both products and production techniques) encouraged in the mid-1980s and in countries The creation of commercial partnerships and buyouts between large firms and small research laboratories or sart-ups that struggle to survive, leading to a phenomenon of concentration of pharmaceutical production and research quickly dominated by the largest companies International organizations that control the funds and structures. For example, this phenomenon of concentration was reflected in France in 30 years (1970-2009) by a fall in the number of pharmaceutical companies, while their size increased and their turnover was almost tenfold (multiplied by 7 in value at Relative prices). Globalization also scatters production: in 1970, the turnover of the French pharmaceutical industry was mainly achieved in France (87\%). This share was down to 53\% in 2010 .

The 1980s are a pivotal period in which the genetic engineering industry is able to patent the living organism (GMO) and where regulation is becoming more stringent in terms of environmental and health risk management. Genomics is progressing rapidly, aided by advances in bioinformatics that dramatically change the way the drug is thought. This is when the first treatments to fight AIDS appear.

Medicines are mainly sold via pharmacy and hospitals.

The global pharmaceutical industry faces several challenges.

Despite the advances in research and medicine, the difficulty of discovering new and effective drugs in a short time. New discovered diseases require more and more research in order to better understand them, which extends the time needed to create an adequate product;

The introduction of generic medicines, which has been encouraged by policies to reduce healthcare costs, in the various developed countries. The generic market is expected to grow annually by $9 \%$ to reach 75 billion Euros in 2008 ( $\$ 100$ billion) (estimated in 2005);

The utmost vigilance of the health authorities American FDA, European EMA, etc. - in view of the therapeutic contributions of the new products and their side effects. There are fewer and fewer marketing authorizations;

The rise of biotechnology, essential in the discovery of new molecules, but a culture different from the original chemical culture of laboratories. The biotech sector accounted for $7 \%$ of the pharmaceutical industry market in 2006. It is expected to provide the industry 
with the best growth potential, while changing the ecosystem and the issues facing the industry.

If the health needs are endless, the resources that can be devoted to them are limited. Public or private healthcare reimbursement schemes attempt to curb drug use by volume and value: Incentives for the use of generics, reimbursements, etc. In some countries, taxes are established directly on pharmaceutical laboratories.

To meet these challenges:

The laboratories are attempting to shorten the time required to discover and market new medicines while ensuring the quality of their products;

They strive to gain real expertise and innovation in key markets (diabetes, cardiovascular disease, cancer or vaccines); They are trying to increase the number of high-potential products in their research portfolio.

The creation of a research portfolio consisting of:

Highly specialized products whose expertise is difficult to reproduce by competition; Products for elderly clients in rich countries and helping them to improve their general health (hypertension, bronchitis, asthma, diabetes, cancer, etc.) and thus their survival; New products with the capacity to become mass medicines.

Machines for the medical industry allow research, development, sampling and medical analysis in the chemistry and laboratory industries. Several types of machines are available: Electrocardiogram, medical gas mixer, orthodontic appliances, etc.

An old mechanism, highly used in the world of medical devices, is the one with rigid memory, or with cam and follower.

The cam and follower mechanisms have spread the first time they were used in the wars of tissue (automated tissue machines).

The emergence and development of internal combustion engines, with valves, Otto or Diesel:

In 1680, Dutch physicist Christian Huygens designs the first internal combustion engine (Petrescu, 2008).

In 1807, the Swiss Francois Isaac de Rivaz invented an internal combustion engine that used a liquid mixture of hydrogen and oxygen as fuel. However, Rivaz's engine for its new engine has been a major failure, so its engine has gone dead, with no immediate application (Petrescu, 2008).

In 1824, English engineer Samuel Brown adapted a steam engine to make it work with gasoline (Petrescu, 2008).

In 1858, the Belgian engineer Jean Joseph Etienne Lenoir invented and patented two years later, practically the first real-life internal combustion engine with sparkignition, liquid gas (extracted from coal), a two-stroke engine. In 1863, the Belgian Lenoir is the one who adapts to his engine a carburetor by making it work with oil (or gasoline) (Petrescu, 2008).
In 1862, French engineer Alphonse Beau de Rochas first patented the four-stroke internal combustion engine (but without building it) (Petrescu, 2008).

It is the merit of the German engineers Eugen Langen and Nikolaus August Otto to build (physically, practically the theoretical model of the French Rochas), the first four-stroke internal combustion engine in 1866, with electric ignition, charging and distribution in a form advanced (Petrescu, 2008).

Ten years later (in 1876), Nikolaus August Otto patented his engine (Petrescu, 2008).

In the same year (1876), Sir Dougald Clerk, sets the two-stroke engine of the Belgian Lenoir, (bringing it to the shape known today) (Petrescu, 2008).

In 1885 Gottlieb Daimler arranged a four-stroke internal four-stroke internal combustion engine with a single vertical cylinder and an improved carburetor (Petrescu, 2008).

A year later, his compatriot Karl Benz brings some improvements to the four-stroke gasoline engine. Both Daimler and Benz were working new engines for their new cars (so famous) (Petrescu, 2008).

In 1889, Daimler improves the four-stroke internal combustion engine, building a "two cylinder in V" and bringing distribution to today's classic form, "with mushroom-shaped valves." (Petrescu, 2008).

In 1890, Wilhelm Maybach built the first four-cylinder internal combustion (Petrescu, 2008).

In 1892, German engineer Rudolf Christian Karl Diesel invented the compression ignition engine, (Petrescu, 2008) and with fuel injection, shortly the diesel engine. The first diesel engines were designed (even from the design) to work with biofuels (this great inventor, Diesel, has obviously thought of at times when oil will be less and more expensive). Thus the first model presented by Diesel worked with vegetable oil squeezed from peanuts (peanuts).

Later, it was adapted to diesel, which could not be used in gasoline engines because diesel had a too low octane figure and the Otto engine (then carburetor and spark ignition) was self-ignition, as it does today when fuel Used do not have the high octane number. Only two-stroke carburetors can cope with heavier fuels, i.e., petrol and lower octane blends, but with diesel oil they too get tough and they start to self-ignite. Low octane diesel fuel fits perfectly with diesel fuel and self-ignition diesel engines as well as many other vegetable oils. It should also be noted that diesel engines are eliminated from the start by compressing only the air, the fuel being introduced when the compression is finished by injection and spraying under pressure. It automatically ignites due to high pressures (as a result of air compression). By burning it greatly increases the temperature which further increases the pressure in the combustion chamber producing motor (expansion) time. 
Today, Otto engines have eliminated carburetors by injecting diesel fuel, but still using spark ignition spark plugs. In general, the Delco was replaced by an electronic ignition. The diesel engines also have a cold-start system, that is, only when the cold engine is started and then automatically disconnects. They could be excluded if the air introduced into the engine were preheated (only for diesel engines where heavy fuel oils, grease, diesel or vegetable oils are very easily ignited with a low octane rating and this is not possible for light fuels with large octane numbers, Gasoline, gas, alcohols, used with Otto spark-ignition engines). It should be noted that both the Otto and the Diesel engines operate in a four-stroke, fourstroke, four-stroke, four-stroke, four-stroke engine, both with compressed air and fuel injection. The first ones have ignition, the latter have self-ignition.

Two-stroke Lenoir-Clerk engines can also be Otto (spark ignition) and diesel (self-ignition) engines, depending on their design and fuel used. However, the most common are Otto classic, spark-ignited, carbureted and instead of distribution window valves, so the twostroke engines did not contribute to the development of valve delivery mechanisms.

Moreover, the first valve mechanisms did not come from cars, but from trains, which were used in steam locomotives.

The first valve mechanisms appeared in 1844, being used in steam locomotives; they were designed and built by the Belgian mechanical engineer Egide Walschaerts (Fig. 1) (Petrescu, 2008).

The first cam mechanisms are used in England and the Netherlands for wars. In 1719, in England, some John Kay opens in a five-story building a filth (Petrescu, 2008). With a staff of over 300 women and children, this would be the world's first factory. He also becomes famous by inventing the flying sword, which makes the tissue much faster. But the cars were still manually operated. It was only by 1750 that the textile industry was to be revolutionized by the widespread application of this invention. Initially, the weavers opposed it, destroying flying sabers and banishing the inventor. By 1760 , the wars and the first factories appeared in the modern sense of the word. It took the first engines. For over a century, Italian Giovanni Branca had proposed using steam to drive turbines. Subsequent experiments were not satisfying.

In France and England, brand inventors, such as Denis Papin or the Worcester Marquis, came up with new ideas (Petrescu, 2008). At the end of the seventeenth century, Thomas Savery had already built the "friend of the miner", a steam engine that put into operation a pump to remove water from the galleries.

Thomas Newcomen has made the commercial version of the steam pump and engineer James Watt develops and adapts a speed regulator that improves the engine's net (Petrescu, 2008).

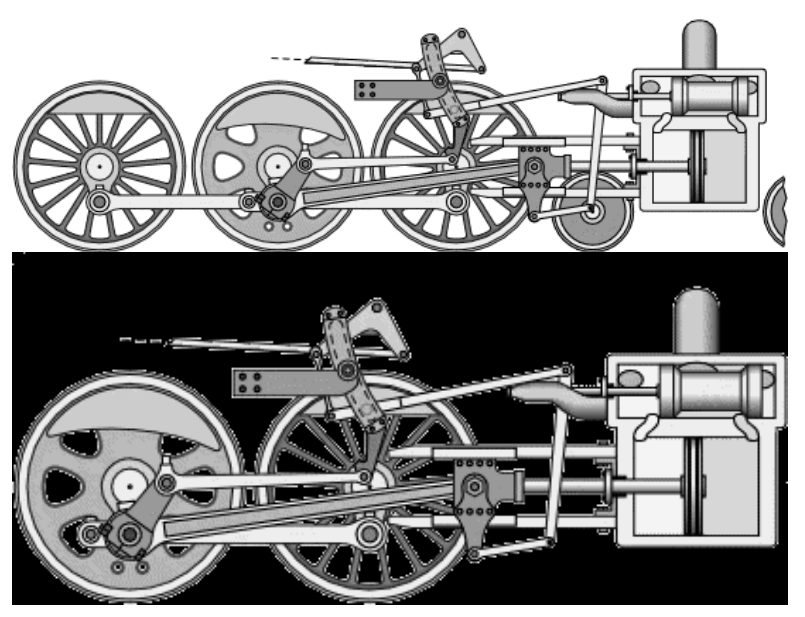

Fig. 1. The first valve mechanisms

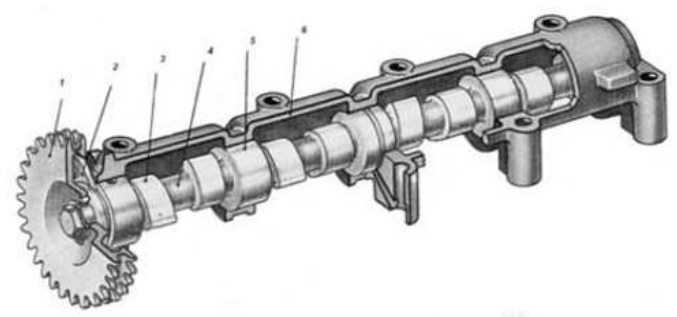

1. - Chain wheel

2. - Axial shaft attachment

3. - Cam

4. - The unprocessed area distribution shaft

5. - Fus palier

6. - The housing
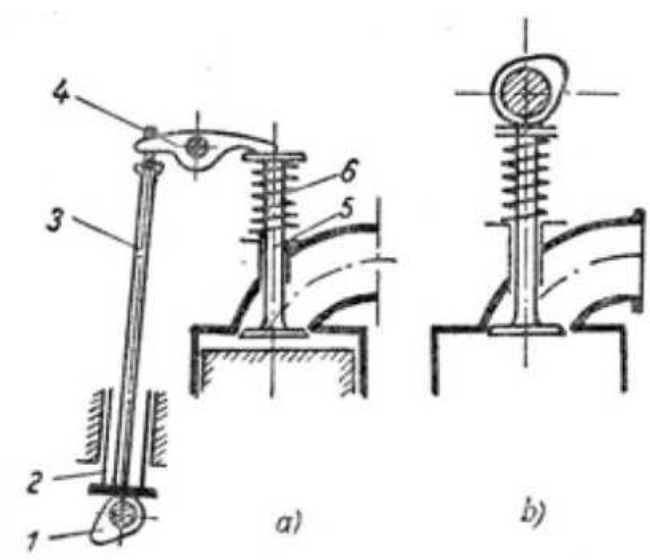

1. - Distribution shaft

2. - Tachet

3. - Pushing rod

4. - Culbutor

5. - Valve

6. - Valve spring

a) - Classic model with rod and rocker

b) - Compact version

Fig. 2. The camshaft diagrams and the distribution mechanism 
Together with Mathiew Boulton, he built the first steam-powered engines and in less than half a century, the wind that had fueled more than 3,000 years ago, the propulsion power at sea now only inflates pleasure boats (Petrescu, 2008). In 1785, the first steam powered steamer came into operation, followed quickly by a few dozen (Petrescu, 2008). The first distribution mechanisms occur with four-stroke engines for cars.

The camshaft diagrams and the distribution mechanism can be seen in Fig. 2 (Petrescu, 2008).

Over the past 25 years, a number of variants have been used to increase the number of valves on a cylinder; From 2 valves per cylinder to just 12 valves/cylinder; but returned to the simpler versions with $2,3,4$, or 5 valves/cylinder. A larger inlet or outlet area can also be provided with a single valve, but when there is more, a variable distribution can be achieved on a higher speed line.

Figure 3 shows a state-of-the-art balanced distribution mechanism with four valves per cylinder, two for intake and two for exhaust; Has returned to the classic mechanism with pushing and cranking rod, because the dynamics of this model of the mechanism is much better (than the model without the clavator). The Swedish builder even considered that the dynamics of the classic mechanism used by replacing the classic stick with the sole by roller can be improved (Petrescu, 2008).

The modular combustion chamber has a unique design of the valve actuator. The valve springs exert great forces to ensure their rapid closure. The forces for their opening are provided by camshaft driven camshafts.

\section{Economy}

Taps and cams are large, ensuring smooth and precise action on the valves. This is reflected in low fuel consumption.

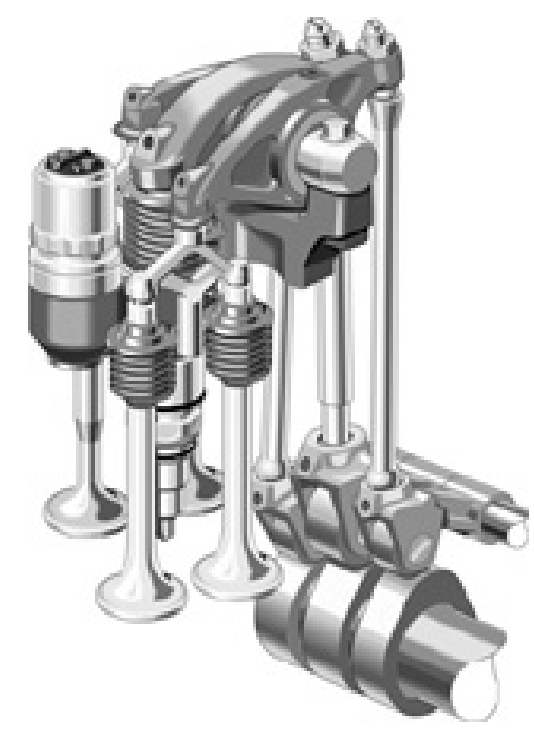

Fig. 3. The Scania distribution mechanism

\section{Reduced Pollutant Emissions}

The accuracy of the distribution mechanism is a vital factor in engine efficiency and clean combustion.

\section{Cost of Operation}

An important benefit brought by the size of the followers is their low wear rate. This reduces the need for adjustments. Valve operation remains constant over a long period of time. If adjustments are required, they can be made quickly and easily (Petrescu, 2008).

Figure 4 shows the kinematic diagram of a 4 -valve variable displacement mechanism on the cylinder; the first valve opens the normal valve and the second one with phase shift (the Peugeot-Citroen hybrid engine in 2006) (Petrescu, 2008).

Almost all current models have stabilized at four valves per cylinder to achieve a variable distribution (see also Volkswagen models).

In 1971, K. Hain proposed a method of optimizing the cam mechanism to obtain an optimal (maximum) transmission angle and a minimum acceleration (Hain, 1971) at the output. In 1979, F. Giordano investigates the influence of measurement errors in the cinematic analysis of the cam (Giordana et al., 1979). In 1985, P. Antonescu presented an analytical method for the synthesis of the cam and flat follower mechanism (Antonescu and Petrescu, 1985; 1989; Antonescu et al., $1985 \mathrm{a} ; 1985 \mathrm{~b} ; 1986 ; 1987 ; 1988 ; 1994)$ and the rocker mechanism (Antonescu et al., 1997; 2000a; 2000b; 2001). Angeles and Lopez-Cajun (1988) present optimal synthesis of the cam mechanism and oscillating flat stick.

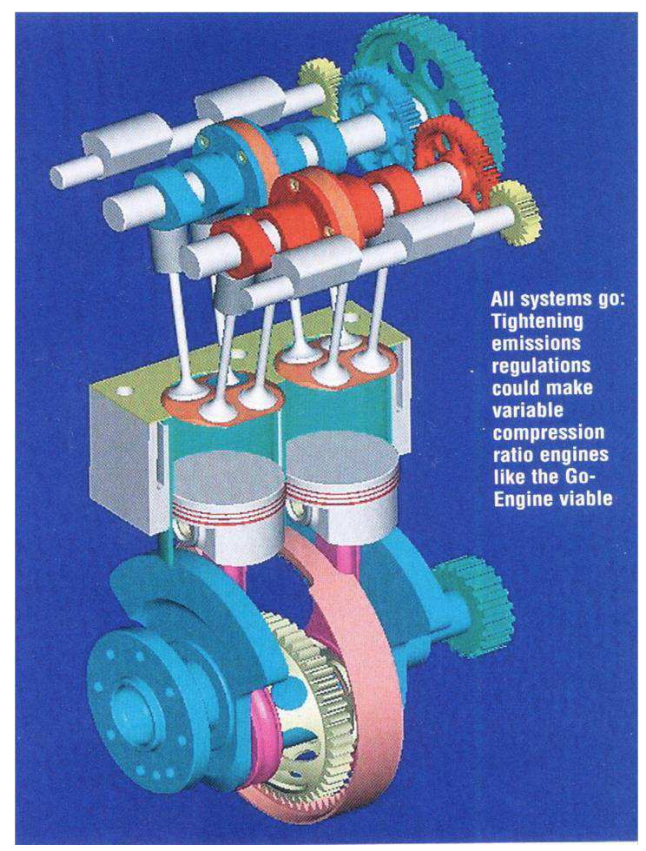

Fig. 4. The kinematic diagram of a 4-valve variable displacement mechanism 
In 2001, Dinu Taraza analyzes the influence of the cam profile, on the angular velocity variation of the shaft and on the internal combustion engine power, load, consumption and emissions (Taraza et al., 2001; Taraza, 2002; 2003a; 2003b). In 2005, Petrescu and R. Petrescu presented a method of synthesis of the rotary camshaft profile with rotary or rotatable tappet, flat or roller, for obtaining high yields at the exit (Petrescu and Petrescu, 1995a; 1995b; 1997a; 1997b; 1997c; 2000a; 2000b; 2002a; 2002b; 2003; 2005a; 2005b; 2005c; 2005d; 2005e; Petrescu et al., 2002a; 2002b; 2005).

\section{Materials and Methods}

The first DISTRIBUTION MECHANISMS (or classical distribution mechanisms) used a rotating cam and a solenoid slide (Fig. 5). How these mechanisms are basic and today will continue to study these types of mechanisms. Figure 5 shows the kinematic diagram of the classic distribution mechanism in two consecutive positions. With an interrupted line, the initial position was represented (in which the mechanism has the stick in the lowest position where $s=0$, then it will rise) and the cam that rotates clockwise with a constant angular speed W is located at point $A_{0}$ (the contact point between the cam profile base profile and the cam lift profile), being a special point marking the beginning of the pushpull movement imposed by the cam profile. With a continuous line, the cam lift profile (located in any position of the lifting phase) is represented. A is the point of contact between the cam and the follower when the mechanism is in any position of lifting; $r_{0}$ is the radius of the base circle of the camshaft; $s_{0}$ (or the existing height in the zero position) is identical to the radius $r_{0} ; s$ (the stroke for any position of the mechanism in the lifting phase) is the law of motion of the follower imposed by cam (the cam profile) and is a function of the cam position angle, $\varphi$ (the camshaft rotation angle).

The geometric-kinematic synthesis of the mechanism in Fig. 5 can be made the fastest (most simple) by using the Cartesian coordinate method.

Pattern 2 occupies the lowest position when in the initial position 0 . The cam 1 rotates constantly and at a speed $\omega$ starting to lift the stick from the initial position 0 by going to a maximum height after which it starts to come back to a moment on the base circle of the cam, where he stays until the next kinematic lifting and lowering cycle begins. The figure shows two positions of the mechanism. The initial 0 , in which the picking starts and any position in the lift. We generally have four important segments on the cam, corresponding to so many phases that make up the cinematic cycle of the mechanism. Lifting (climbing) phase, stopping phase on the cams top circle, lowering (returning) phase and last, the camming phase on the cam ring.

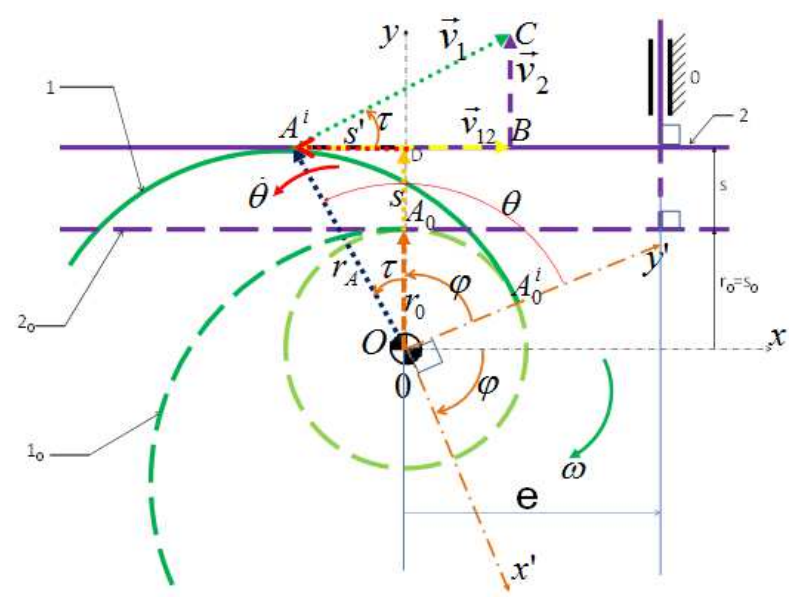

Fig. 5. The kinematic scheme of the classic distribution mechanism

The point $A^{0}$, which marks the point where the cam lifting profile starts (the point of connection between the base circle and the cam lifting line), is at the same time the point of contact between the cam and the follower in the zero position of the follower (the most bottom of the tappet).

The cam is rotating (together with the camshaft) clockwise with the angular velocity $\omega$ (angular velocity of the camshaft), describing the angle $\varphi$; this rotation can be seen on the base circle between the two particular points, $A^{0}$ and $A^{0 i}$.

The vector $r_{A}=O A$ (which represents the distance between the contact point $A$ and the centre of cam $O$ ), has rotated with the angle $\tau$ anticlockwise. If one measures the angle $\theta$, which positions the general vector, $r_{A}$, in function of the particular vector, $r_{A 0}$, one obtains the relation (0) (Petrescu, 2008):

$\theta=\phi+\tau$

where, $r_{A}$ represents the vector $\vec{r}_{A}$ module and $\theta_{A}$ is the phase angle of the vector $\vec{r}_{A}$.

The angular velocity of the vector $\vec{r}_{A}$ is $\dot{\theta}_{A}$ which is a function of the angular velocity of the camshaft, $\omega$ and of the angle $\varphi$ (by the movement laws $s(\varphi), \mathrm{s}^{\prime}(\varphi)$, $\mathrm{s}$ ' $(\varphi))$. The follower isn't acted directly by the angle $\varphi$ and the angular velocity $\omega$, it's acted by the vector $\vec{r}_{A}$, which has the module $r_{A}$, the position angle $\theta_{A}$ and the angular velocity $\dot{\theta}_{A}$. From here we deduce a particular (dynamic) kinematics, the classical kinematics being just static and an approximate kinematics.

Kinematic one defines the next velocities (Fig. 5).

$\vec{v}_{1}=$ the cam's velocity; which is the velocity of the vector $\vec{r}_{A}$, in the point $A$; now the classical relation (1) 
becomes an approximate relation and the real relation takes the form (2):

$$
\begin{aligned}
& v_{1}=r_{A} \cdot \omega \\
& v_{1}=r_{A} \cdot \dot{\theta}_{A}
\end{aligned}
$$

The velocity $\vec{v}_{1}=A C$ is separating into the velocity $\vec{v}_{2}=B C$ (the follower's velocity which acts on its axe, vertically) and $\vec{v}_{12}=A B$ (the slide velocity between the two profiles, the sliding velocity between the cam and the follower, which works along the direction of the commune tangent line of the two profiles in the contact point).

Because usually the cam profile is synthesis for the classical module $C$ with the $A D=s$, known, one can write the relations:

$$
\begin{aligned}
& r_{A}^{2}=\left(r_{0}+s\right)^{2}+s^{\prime 2} \\
& r_{A}=\sqrt{\left(r_{0}+s\right)^{2}+s^{\prime 2}} \\
& \cos \tau=\frac{r_{0}+s}{r_{A}}=\frac{r_{0}+s}{\sqrt{\left(r_{0}+s\right)^{2}+s^{\prime 2}}} \\
& \sin \tau=\frac{A D}{r_{A}}=\frac{s^{\prime}}{r_{A}}=\frac{s^{\prime}}{\sqrt{\left(r_{0}+s\right)^{2}+s^{\prime 2}}} \\
& v_{2}=v_{1} \cdot \sin \tau=r_{A} \cdot \dot{\theta}_{A} \cdot \frac{s^{\prime}}{r_{A}}=s^{\prime} \cdot \dot{\theta}_{A}
\end{aligned}
$$

Now, the follower's velocity isn't $\dot{s}\left(v_{2} \neq \dot{s} \equiv s^{\prime} \cdot \omega\right)$, but it's given by the relation (9). In the case of the classical distribution mechanism the transmitting function $\mathrm{D}$ is given by the relations (8):

$$
\begin{aligned}
& \dot{\theta}_{A}=D . \omega \\
& D=\frac{\dot{\theta}_{A}}{\omega} \\
& v_{2}=s^{\prime} . \dot{\theta}_{A}=s^{\prime} \cdot D . \omega
\end{aligned}
$$

The determining of the sliding velocity between the profiles is made with the relation (10):

$$
v_{12}=v_{1} \cdot \cos \tau=r_{A} \cdot \dot{\theta}_{A} \cdot \frac{r_{0}+s}{r_{A}}=\left(r_{0}+s\right) \cdot \dot{\theta}_{A}
$$

The angles $\tau$ and $\theta_{A}$ will be determined and also their first and second derivatives. The $\tau$ angle has been determined from the triangle $O D A^{i}$ (Fig. 5) with the relations (11-13):

$$
\begin{aligned}
& \sin \tau=\frac{s^{\prime}}{\sqrt{\left(r_{0}+s\right)^{2}+s^{\prime 2}}} \\
& \cos \tau=\frac{r_{0}+s}{\sqrt{\left(r_{0}+s\right)^{2}+s^{\prime 2}}} \\
& \operatorname{tg} \tau=\frac{s^{\prime}}{r_{0}+s}
\end{aligned}
$$

One derives (11) in function of $\varphi$ angle and obtains (14):

$$
\tau^{\prime} \cdot \cos \tau=\frac{s^{\prime \prime} . r_{A}-s^{\prime} \cdot \frac{\left(r_{0}+s\right) . s^{\prime}+s^{\prime} . s^{\prime \prime}}{r_{A}}}{\left(r_{0}+s\right)^{2}+s^{\prime 2}}
$$

The relation (14) will be written in the form (15):

$$
\tau^{\prime} \cdot \cos \tau=\frac{s^{\prime \prime} .\left(r_{0}+s\right)^{2}+s^{\prime \prime} . s^{\prime 2}-s^{\prime 2} \cdot\left(r_{0}+s\right)-s^{\prime 2} . s^{\prime \prime}}{\left[\left(r_{0}+s\right)^{2}+s^{\prime 2}\right] \cdot \sqrt{\left(r_{0}+s\right)^{2}+s^{\prime 2}}}
$$

From the relation (12) one extracts the value of $\cos \tau$, which will be introduced in the left term of the expression (15); then one reduces $s^{\prime \prime} . s^{\prime 2}$ from the right term of the expression (15) and obtain the relation (16).

After some simplifications the relation (17), which represents the expression of $\tau$, is finally obtained.

$$
\begin{aligned}
& \tau^{\prime} \cdot \frac{r_{0}+s}{\sqrt{\left(r_{0}+s\right)^{2}+s^{\prime 2}}} \\
& =\frac{\left(r_{0}+s\right) \cdot\left[s^{\prime \prime} \cdot\left(r_{0}+s\right)-s^{\prime 2}\right]}{\left[\left(r_{0}+s\right)^{2}+s^{\prime 2}\right] \cdot \sqrt{\left(r_{0}+s\right)^{2}+s^{\prime 2}}} \\
& \tau^{\prime}=\frac{s^{\prime \prime} \cdot\left(r_{0}+s\right)-s^{\prime 2}}{\left(r_{0}+s\right)^{2}+s^{\prime 2}}
\end{aligned}
$$

Now, when $\tau$ has been explicitly deduced, the next derivatives can be determined. The expression (17) will be derived directly and one obtains for the beginning the relation (18):

$$
\begin{aligned}
& \tau^{\prime \prime}= \\
& \frac{\left[s^{\prime \prime \prime}\left(r_{0}+s\right)+s^{\prime \prime} s^{\prime}-2 s^{\prime} s^{\prime \prime}\right]\left[\left(r_{0}+s\right)^{2}+s^{\prime 2}\right]}{\left[\left(r_{0}+s\right)^{2}+s^{\prime 2}\right]^{2}} \\
& -\frac{2\left[s^{\prime \prime}\left(r_{0}+s\right)-s^{\prime 2}\right]\left[\left(r_{0}+s\right) s^{\prime}+s^{\prime} s^{\prime \prime}\right]}{\left[\left(r_{0}+s\right)^{2}+s^{\prime 2}\right]^{2}}
\end{aligned}
$$


The terms from the first bracket of the numerator $(s ' . s$ ') are reduced and then one draws out s' from the fourth bracket of the numerator and obtains the expression (19):

$$
\begin{gathered}
\tau^{\prime \prime}=\frac{\left[s^{\prime \prime \prime} \cdot\left(r_{0}+s\right)-s^{\prime} \cdot s^{\prime \prime}\right] \cdot\left[\left(r_{0}+s\right)^{2}+s^{\prime 2}\right]}{\left[\left(r_{0}+s\right)^{2}+s^{\prime 2}\right]^{2}} \\
-\frac{2 . s^{\prime} \cdot\left[s^{\prime \prime} \cdot\left(r_{0}+s\right)-s^{\prime 2}\right] \cdot\left[r_{0}+s+s^{\prime \prime}\right]}{\left[\left(r_{0}+s\right)^{2}+s^{\prime 2}\right]^{2}}
\end{gathered}
$$

Now it can calculate $\theta_{A}$, with its first two derivatives, $\dot{\theta}_{A}$ and $\ddot{\theta}_{A}$. We will write $\theta$ instead of $\theta_{A}$, to simplify the notation. One can determine (20) which is the same of $(0)$ :

$$
\theta=\tau+\phi
$$

One derives (20) and obtains the relation (21):

$$
\dot{\theta}=\dot{\tau}+\dot{\phi}=\tau^{\prime} . \omega+\omega=\omega .\left(1+\tau^{\prime}\right)=D . \omega
$$

One derives twice (20), or derives (21) and obtains (22):

$$
\ddot{\theta}=\ddot{\tau}+\ddot{\phi}=\tau " \cdot \omega^{2}=D^{\prime} \cdot \omega^{2}
$$

One can write now the Transmission functions, $D$ and $D^{\prime}$ (for the classical module, $C$ ), in the forms (23-24):

$$
\begin{aligned}
& D=\tau^{\prime}+1 \\
& D^{I}=\tau^{\prime \prime}
\end{aligned}
$$

To calculate the follower's velocity (25) we need the expression of the transmission function, $D$ :

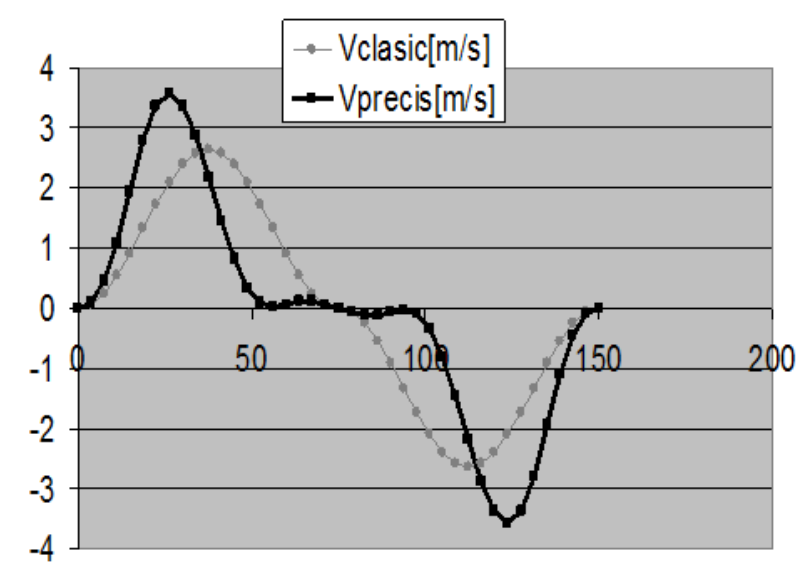

(a)

$$
v_{2}=s^{\prime} \cdot w=s^{\prime} \cdot \dot{\theta}_{A}=s^{\prime} \cdot \dot{\theta}=s^{\prime} \cdot D \cdot \omega=\dot{s} \cdot D
$$

where:

$w=D . \omega$

For the classical distribution mechanism (Module $C$ ), the variable $\mathrm{w}$ is the same as $\dot{\theta}_{A}$ (see the relation 25). But in the case of $B$ and $F$ modules (at the cam gears where the follower has a roll), the transmitted function $D$ and $\mathrm{w}$ take complex forms. Now, one can determine the acceleration of the follower (27):

$\ddot{y} \equiv a_{2}=\left(s^{\prime \prime} \cdot D+s^{\prime} \cdot D^{\prime}\right) \cdot \omega^{2}$

Figure 6 represents the classical and dynamic kinematics; the velocities (a) and the accelerations (b).

To determine the acceleration of the follower, $s$ ' and $s^{\prime}, D$ and $D^{\prime}, \tau^{\prime}$ and $\tau^{\prime}$ ' are necessary to be known.

The dynamic kinematics diagrams of $v_{2}$ (obtained with relation 25 , Fig. 2a) and $a_{2}$ (obtained with relation 27 , Fig. 2 b), have a more dynamic aspect than one kinematic. One has used the movement law SIN, a rotational speed of the crankshaft $n=5500 \mathrm{rpm}$, a rise angle $\varphi_{u}=75^{\circ}$, a fall angle $\varphi_{d}=75^{\circ}$ (identically with the ascendant angle), a ray of the basic circle of the cam, $r_{0}=17 \mathrm{~mm}$ and a maxim stroke of the follower, $h_{T}=6 \mathrm{~mm}$.

Anyway, the dynamics is more complex, having in view the masses and the inertia moments, the resistant and motor forces, the elasticity constants and the amortization coefficient of the kinematic chain, the inertia forces of the system, the angular velocity of the camshaft and the variation of the camshaft's angular velocity, $\omega$, with the cam's position, $\varphi$ and with the rotational speed of the crankshaft, $\mathrm{n}$.

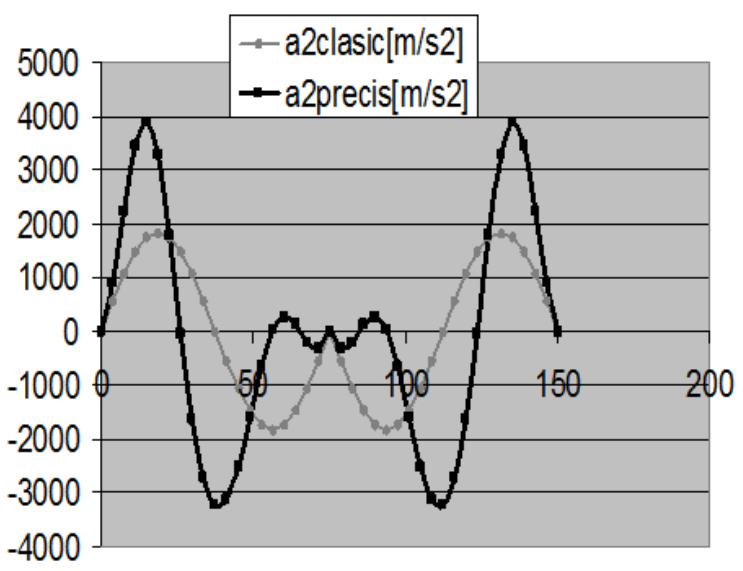

(b)

Fig. 6. The classical and dynamic kinematics; (a) velocities of the follower; (b) accelerations of the follower 


\section{Results}

In the kinematics and the static forces study of the mechanisms one considers the shaft's angular velocity constant, $\dot{\phi}=\omega=$ constant and the angular acceleration null, $\ddot{\phi}=\dot{\omega}=\varepsilon=0$. In reality, this angular velocity $\omega$ isn't constant, but it is variable with the camshaft position, $\varphi$.

In mechanisms with cam and follower the camshaft's angular velocity is variable as well. One shall see further the Lagrange equation, written in the differentiate mode and its general solution (Petrescu, 2008).

The differentiate Lagrange equation has the form (28):

$$
J^{*} . \ddot{\phi}+\frac{1}{2} . J^{* I} . \dot{\phi}^{2}=M^{*}
$$

where, $J^{*}$ is the inertia moment (mass moment, or mechanic moment) of the mechanism, reduced at the crank and $M^{*}$ represents the difference between the motor moment reduced at the crank and the resistant moment reduced at the crank; the angle $\varphi$ represents the rotation angle of the crank (crankshaft). $J^{* I}$ represents the derivative of the mechanic moment in function of the rotation angle $\varphi$ of the crank (29):

$$
\frac{1}{2} \cdot J^{* I}=\frac{1}{2} \cdot \frac{d J^{*}}{d \phi}=L
$$

Using the notation (29), the Equation 28 will be written in the form (30):

$$
J^{*} \ddot{\phi}+L \cdot \dot{\phi}^{2}=M^{*}
$$

One divides the terms by $J^{*}$ and (30) takes the form (31):

$\ddot{\phi}+\frac{L}{J^{*}} \cdot \dot{\phi}^{2}=\frac{M^{*}}{J^{*}}$

The term with $\dot{\phi}^{2}$ will be moved to the right side of the equation and the form (32) will be obtained:

$\ddot{\phi}=\frac{M^{*}}{J^{*}}-\frac{L}{J^{*}} \cdot \dot{\phi}^{2}$

Replacing the left term of the expression (32) with (33) one obtains the relation (34):

$$
\begin{aligned}
& \ddot{\phi}=\frac{d \dot{\phi}}{d t}=\frac{d \dot{\phi}}{d \phi} \cdot \frac{d \phi}{d t}=\frac{d \dot{\phi}}{d \phi} \cdot \dot{\phi}=\frac{d \omega}{d \phi} \cdot \omega \\
& \omega \cdot \frac{d \omega}{d \phi}=\frac{M^{*}}{J^{*}}-\frac{L}{J^{*}} \cdot \omega^{2}=\frac{M^{*}-L \cdot \omega^{2}}{J^{*}}
\end{aligned}
$$

Because, for an angle $\varphi, \omega$ is different from the nominal constant value $\omega_{n}$, one can write the relation (35), where $d \omega$ represents the momentary variation for the angle $\varphi$; the variable $d \omega$ and the constant $\omega_{n}$ lead us to the needed variable, $\omega$.

$\omega=\omega_{n}+d \omega$

In the relation (35), $\omega$ and $d \omega$ are functions of the angle $\varphi$ and $\omega_{n}$ is a constant parameter, which can take different values in function of the rotational speed of the drive-shaft, $n$. At a moment, $\mathrm{n}$ is a constant and $\omega_{n}$ is a constant as well (because $\omega_{n}$ is a function of $n)$. The angular velocity, $\omega$, becomes a function of $n$ too (relation 36):

$\omega(\phi, n)=\omega_{n}(n)+d \omega\left(\phi, \omega_{n}(n)\right)$

With (35) in (34), one obtains the Equation 37:

$\left(\omega_{n}+d \omega\right) \cdot d \omega=\left[\frac{M^{*}}{J^{*}}-\frac{L}{J^{*}} \cdot\left(\omega_{n}+d \omega\right)^{2}\right] . d \phi$

The relation (37) takes the form (38):

$\omega_{n} \cdot d \omega+(d \omega)^{2}=\frac{M^{*}}{J^{*}} \cdot d \phi$
$-\frac{L}{J^{*}} \cdot d \phi \cdot\left[\omega_{n}^{2}+[d \omega)^{2}+2 \cdot \omega_{n} \cdot d \omega\right]$

The Equation 38 will be written in the form (39):

$\omega_{n} \cdot d \omega+(d \omega)^{2}-\frac{M^{*}}{J^{*}} \cdot d \phi+\frac{L}{J^{*}} \cdot d \phi \cdot \omega_{n}^{2}$
$+\frac{L}{J^{*}} \cdot d \phi \cdot(d \omega)^{2}+2 \cdot \frac{L}{J^{*}} \cdot d \phi \cdot \omega_{n} \cdot d \omega=0$

The relation (39) takes the form (40):

$$
\begin{aligned}
& \left(\frac{L}{J^{*}} \cdot d \phi+1\right) \cdot(d \omega)^{2}+2 \cdot\left(\frac{L}{J^{*}} \cdot d \phi+\frac{1}{2}\right) \cdot \omega_{n} \cdot d \omega \\
& -\left(\frac{M^{*}}{J^{*}} \cdot d \phi-\frac{L}{J^{*}} \cdot d \phi \cdot \omega_{n}^{2}\right)=0
\end{aligned}
$$

The relation (40) is an equation of the second degree in $d \omega$. The discriminate of the Equation 40 can be written in the forms (41) and (42):

$$
\begin{aligned}
& \Delta=\frac{L^{2}}{J^{* 2}} \cdot(d \phi)^{2} \cdot \omega_{n}^{2}+\frac{\omega_{n}^{2}}{4}+\frac{L}{J^{*}} \cdot d \phi \cdot \omega_{n}^{2}+\frac{L \cdot M^{*}}{J^{* 2}} \cdot(d \phi)^{2} \\
& +\frac{M^{*}}{J^{*}} \cdot d \phi-\frac{L^{2}}{J^{* 2}} \cdot(d \phi)^{2} \cdot \omega_{n}^{2}-\frac{L}{J^{*}} \cdot d \phi \cdot \omega_{n}^{2}
\end{aligned}
$$




$$
\Delta=\frac{\omega_{n}^{2}}{4}+\frac{L \cdot M^{*}}{J^{* 2}} \cdot(d \phi)^{2}+\frac{M^{*}}{J^{*}} \cdot d \phi
$$

One keeps for $d \omega$ just the positive solution, which can generate positives and negatives normal values (43) and in this mode only normal values will be obtained for $\omega$, for $\Delta<0$ one considers $d \omega=0$ (this case must be not seeing if the equation is correct):

$$
d \omega=\frac{-\frac{L}{J^{*}} \cdot d \phi \cdot \omega_{n}-\frac{\omega_{n}}{2}+\sqrt{\Delta}}{\frac{L}{J^{*}} \cdot d \phi+1}
$$

\section{Observations}

For mechanisms with rotating cam and follower, using the new relations, with $M^{*}$ (the reduced moment of the mechanism) obtained by the writing of the known reduced resistant moment and by the determination of the reduced motor moment by the integration of the resistant moment one frequently obtains some bigger values for $d \omega$, or zones with $\Delta$ negative, with complex solutions for $d \omega$. This fact gives us the obligation to reconsider the method to determine the reduced moment.
If we take into consideration $M^{*}{ }_{r}$ and $M^{*}{ }_{m}$, calculated independently (without integration), one obtains for the mechanisms with cam and follower normal values for $d \omega$ and $\Delta \geq 0$.

In paper (Petrescu and Petrescu, 2005b) were presented the relations to determine the resistant force (44) reduced to the valve and the motor force (45) reduced to the ax of the valve:

$$
\begin{aligned}
& F_{r}^{*}=k \cdot\left(x_{0}+x\right) \\
& F_{m}^{*}=K \cdot(y-x)
\end{aligned}
$$

The reduced resistant moment (46), or the reduced motor moment (47), can be obtained by the resistant or motor force multiplied by the reduced velocity, $x^{\prime}$ :

$$
\begin{aligned}
& M_{r}^{*}=k \cdot\left(x_{0}+x\right) \cdot x^{\prime} \\
& M_{m}^{*}=K \cdot(y-x) \cdot x^{\prime}
\end{aligned}
$$

The dynamics relations used (48-49), have been deduced in the paper (Petrescu and Petrescu, 2005b):

$$
\begin{aligned}
& \Delta X=(-1) \cdot \frac{\left(k^{2}+2 \cdot k \cdot K\right) \cdot s^{2}+2 \cdot k \cdot x_{0} \cdot(K+k) \cdot s+\left[\frac{K^{2}}{K+k} \cdot m_{S}^{*}+(K+k) \cdot m_{T}^{*}\right] \cdot \omega^{2} \cdot\left(D s^{\prime}\right)^{2}}{2 \cdot\left(s+\frac{k \cdot x_{0}}{K+k}\right) \cdot(K+k)^{2}} \\
& X=s-\frac{\left[\frac{K^{2}}{K+k} \cdot m_{S}^{*}+(K+k) \cdot m_{T}^{*}\right] \cdot \omega^{2} \cdot\left(D s^{\prime}\right)^{2}}{2 \cdot\left(s+\frac{k \cdot x_{0}}{K+k}\right) \cdot(K+k)^{2}}-\frac{\left(k^{2}+2 \cdot k \cdot K\right) \cdot s^{2}+2 \cdot k \cdot x_{0} \cdot(K+k) \cdot s}{2 \cdot\left(s+\frac{k \cdot x_{0}}{K+k}\right) \cdot(K+k)^{2}}
\end{aligned}
$$

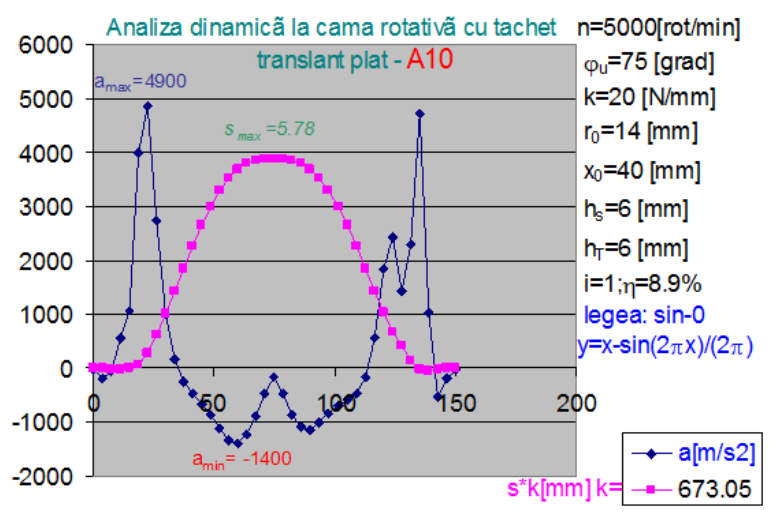

Fig. 7. The dynamic analysis of the law sin, Module C, $\varphi_{u}=$ $75^{0}, n=5000 \mathrm{rpm}$

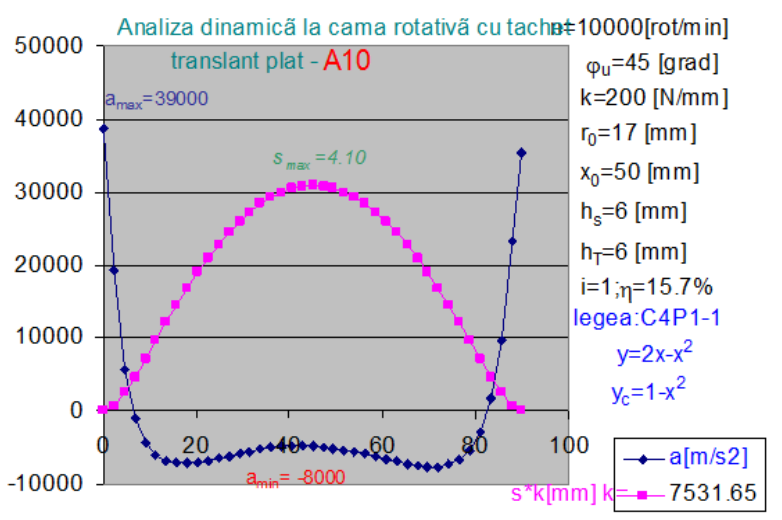

Fig. 8. The dynamic analysis of the new law, C4P, Module C, $\varphi_{u}=45^{0}, n=10000 \mathrm{rpm}$ 


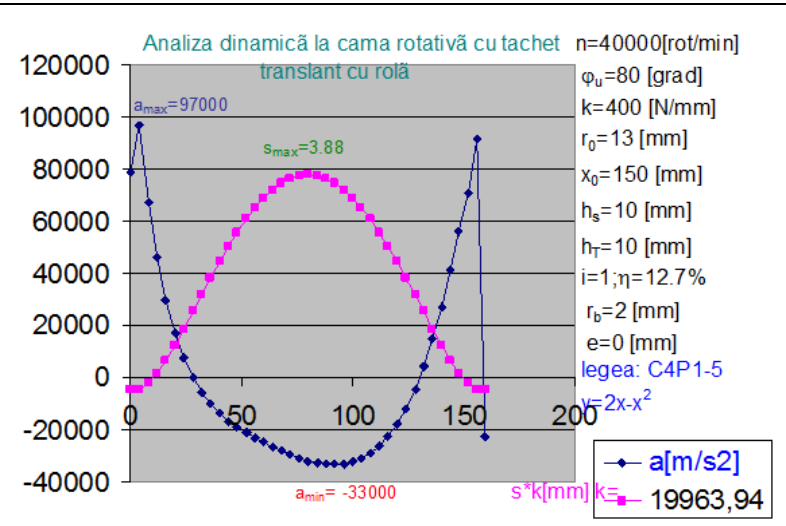

Fig. 9. Law C4P1-5, Module B, $\varphi_{u}=80^{\circ}, n=40000 \mathrm{rpm}$

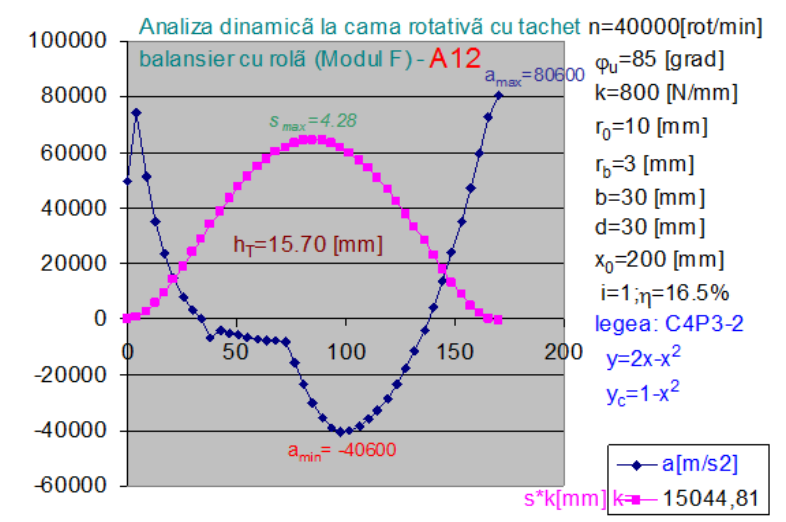

Fig. 10. Law C4P3-2, Module F, $\varphi_{u}=85^{\circ}, n=40000 \mathrm{rpm}$

The dynamic analysis or the classical movement law sin, can be seen in the diagram from Fig. 7 and in Fig. 8 one can see the diagram of an original movement law (C4P) (module C).

Using classic motion laws, the distribution mechanism dynamics quickly depreciates when increasing the rotational speed of the shaft. In order to sustain a high rotation speed, it is necessary to synthesize the cam profile with the proposed new motion laws.

A new and original movement law is presented in the figures number 8, 9 and 10; it allows the increase of the rotational speed to the values: $10000-20000 \mathrm{rpm}$, in the classical module $\mathrm{C}$ presented (Fig. 8). With others modules (B, F) one can obtain 30000-40000 rpm (see Fig. 9 and 10) (Petrescu, 2008).

Geometric-Kinematic Synthesis of a Classic Rotating cam Mechanism and Translatable Flat Stick

A quick method of geometric synthesis is that of Cartesian coordinates (Fig. 5).

In the fixed system $\mathrm{xOy}$, the cartesian coordinates of the point A of contact (belonging to the tappet 2) are given by the projections of the position vector $r_{A}$ on the axes Oxy respectively Oy and have the analytical expressions expressed by the relational system (50):

$$
\left\{\begin{array}{l}
x_{T}=r_{A} \cdot \cos \left(\phi+\tau+\frac{\pi}{2}-\phi\right)=r_{A} \cdot \cos \left(\frac{\pi}{2}+\tau\right)=-r_{A} \cdot \sin \tau \\
=-r_{A} \cdot \frac{s^{\prime}}{r_{A}}=-s^{\prime} \\
y_{T}=r_{A} \cdot \sin \left(\phi+\tau+\frac{\pi}{2}-\phi\right)=r_{A} \cdot \sin \left(\frac{\pi}{2}+\tau\right)=r_{A} \cdot \cos \tau \\
=r_{A} \cdot \frac{r_{0}+s}{r_{A}}=r_{0}+s
\end{array}\right.
$$

In the $\mathrm{x}^{\prime} \mathrm{O} \mathrm{y}$ 'mobile system, the Cartesian coordinates of the point A of contact (belonging to the cam-shaped profile 1 which rotated with the angle $\omega$ ) are given by the systems relations (51-52):

$$
\begin{aligned}
& \left\{\begin{array}{l}
x_{C}=r_{A} \cdot \cos \left(\phi+\tau+\frac{\pi}{2}-\phi+\phi\right)=r_{A} \cdot \cos \left(\frac{\pi}{2}+\tau+\phi\right) \\
=r_{A} \cdot \sin (-\phi-\tau)=-r_{A} \cdot \sin (\phi+\tau) \\
=-r_{A} \cdot(\sin \phi \cdot \cos \tau+\sin \tau \cdot \cos \phi) \\
=-r_{A} \cdot \frac{r_{0}+s}{r_{A}} \cdot \sin \phi-r_{A} \cdot \frac{s^{\prime}}{r_{A}} \cdot \cos \phi \\
=-\left(r_{0}+s\right) \cdot \sin \phi-s^{\prime} \cdot \cos \phi \\
y_{C}=r_{A} \cdot \sin \left(\phi+\tau+\frac{\pi}{2}-\phi+\phi\right)=r_{A} \cdot \sin \left(\frac{\pi}{2}+\tau+\phi\right) \\
=r_{A} \cdot \cos (-\phi-\tau)=r_{A} \cdot \cos (\phi+\tau) \\
=r_{A} \cdot(\cos \phi \cdot \cos \tau-\sin \tau \cdot \sin \phi) \\
=r_{A} \cdot \frac{r_{0}+s}{r_{A}} \cdot \cos \phi-r_{A} \cdot \frac{s^{\prime}}{r_{A}} \cdot \sin \phi \\
=\left(r_{0}+s\right) \cdot \cos \phi-s^{\prime} \cdot \sin \phi
\end{array}\right. \\
& \left\{\begin{array}{l}
x_{C}=-s^{\prime} \cdot \cos \phi-\left(r_{0}+s\right) \cdot \sin \phi \\
y_{C}=\left(r_{0}+s\right) \cdot \cos \phi-s^{\prime} \cdot \sin \phi
\end{array}\right.
\end{aligned}
$$

Note: The displacement is between the cam and cam axis and does not influence the geometric-kinematic synthesis of the mechanism.

\section{Force Distribution and Performance Determination at a Classic Rotating cam Mechanism and Translatable Flat Tappet}

The consumed motor force, $F_{c}$, perpendicular to $A$ on the vector $r_{A}$, is divided into two components: (a) $F_{m}$, which represents the useful force, or the engine force reduced to the barrel; (b) $F_{y}$, which is the sliding force between the two profiles of the cam and the follower, (Fig. 11) and the relations (53-62): 


$$
\begin{aligned}
& F_{m}=F_{c} \cdot \sin \tau \\
& v_{2}=v_{1} \cdot \sin \tau \\
& P_{u}=F_{m} \cdot v_{2}=F_{c} \cdot v_{1} \cdot \sin ^{2} \tau \\
& P_{c}=F_{c} \cdot v_{1} \\
& \eta_{i}=\frac{P_{u}}{P_{c}}=\frac{F_{c} \cdot v_{1} \cdot \sin ^{2} \tau}{F_{c} \cdot v_{1}}=\sin ^{2} \tau=\cos ^{2} \delta \\
& \sin ^{2} \tau=\frac{s^{\prime 2}}{r_{A}^{2}}=\frac{s^{\prime 2}}{\left(r_{0}+s\right)^{2}+s^{\prime 2}} \\
& F_{\psi}=F_{c} \cdot \cos \tau \\
& v_{12}=v_{1} \cdot \cos \tau \\
& P_{\psi}=F_{\psi} \cdot v_{12}=F_{c} \cdot v_{1} \cdot \cos ^{2} \tau \\
& \psi_{i}=\frac{P_{\psi}}{P_{c}}=\frac{F_{c} \cdot v_{1} \cdot \cos ^{2} \tau}{F_{c} \cdot v_{1}}=\cos ^{2} \tau=\sin ^{2} \delta
\end{aligned}
$$

Dynamic Synthesis of Rotative Cam with Plate Translated Follower (COS-COS Law). Application

A flat-rotating rotating cam is using cos-cos (laws of climbing and lowering).

Determine the dynamic parameters and complete the following Table 1.

Then draw the diagram.

The following parameters are given:
$R_{0}=0.013[\mathrm{~m}] ; h=0.008[\mathrm{~m}] ; x_{0}=0.03[\mathrm{~m}] ; \varphi_{u}=$ $\pi / 2 ; \varphi_{c}=\pi / 2 ; K=5000000[\mathrm{~N} / \mathrm{m}] ; k=20000$ $[\mathrm{N} / \mathrm{m}] ; m_{T}=0.1[\mathrm{~kg}] ; M_{c}=0.2[\mathrm{~kg}] ; n_{\text {motor }}=5500$ [rot $/ \mathrm{min}]$.

Way of working (63):

It determines the laws of motion with relationships

$$
\left\{\begin{array}{l}
s=\frac{h}{2}-\frac{h}{2} \cdot \cos \left(\pi \cdot \frac{\phi}{\phi_{u}}\right) \quad s_{c}=\frac{h}{2}+\frac{h}{2} \cdot \cos \left(\pi \cdot \frac{\phi}{\phi_{c}}\right) \\
s^{\prime} \equiv v_{r}=\frac{\pi \cdot h}{2 \cdot \phi_{u}} \cdot \sin \left(\pi \cdot \frac{\phi}{\phi_{u}}\right) \quad s_{c}^{\prime}=-\frac{\pi \cdot h}{2 \cdot \phi_{c}} \cdot \sin \left(\pi \cdot \frac{\phi}{\phi_{c}}\right) \\
s^{\prime \prime} \equiv a_{r}=\frac{\pi^{2} \cdot h}{2 \cdot \phi_{u}^{2}} \cdot \cos \left(\pi \cdot \frac{\phi}{\phi_{u}}\right) \quad s_{c}^{\prime \prime}=-\frac{\pi^{2} \cdot h}{2 \cdot \phi_{c}^{2}} \cdot \cos \left(\pi \cdot \frac{\phi}{\phi_{c}}\right) \\
s^{\prime \prime \prime} \equiv \alpha_{r}=-\frac{\pi^{3} \cdot h}{2 \cdot \phi_{u}^{3}} \cdot \sin \left(\pi \cdot \frac{\phi}{\phi_{u}}\right) \quad s_{c}^{\prime \prime \prime}=\frac{\pi^{3} \cdot h}{2 \cdot \phi_{c}^{3}} \cdot \sin \left(\pi \cdot \frac{\phi}{\phi_{c}}\right)
\end{array}\right.
$$

Table 1. The dynamics of the classic cam (the co sinusoidal motion law)

\begin{tabular}{llllllllll}
\hline$\varphi[\mathrm{deg}]$ & 0 & 10 & 20 & $\ldots$ & $\varphi_{\mathrm{u}}$ & 0 & 10 & $\ldots$ & $\varphi_{\mathrm{c}}$ \\
\hline $\mathrm{s}[\mathrm{m}]$ & & & & & & & & & \\
$\mathrm{s}^{\prime}[\mathrm{m}]$ & & & & & & & & \\
$\mathrm{s}^{\prime},[\mathrm{m}]$ & & & & & & & & \\
$\mathrm{s}^{\prime},{ }^{\prime}[\mathrm{m}]$ & & & & & & & & \\
$\omega^{2}\left[\mathrm{~s}^{-2}\right]$ & & & & & & & & \\
$\varepsilon\left[\mathrm{s}^{-2}\right]$ & & & & & & & & \\
$\mathrm{x}[\mathrm{m}]$ & & & & & & & & \\
$\mathrm{x},[\mathrm{m}]$ & & & & & & & & \\
$\mathrm{x},{ }^{\prime}[\mathrm{m}]$ & & & & & & & & \\
$\ddot{x}\left[\mathrm{~ms}^{-2}\right]$ & & & & & & & & \\
\hline
\end{tabular}

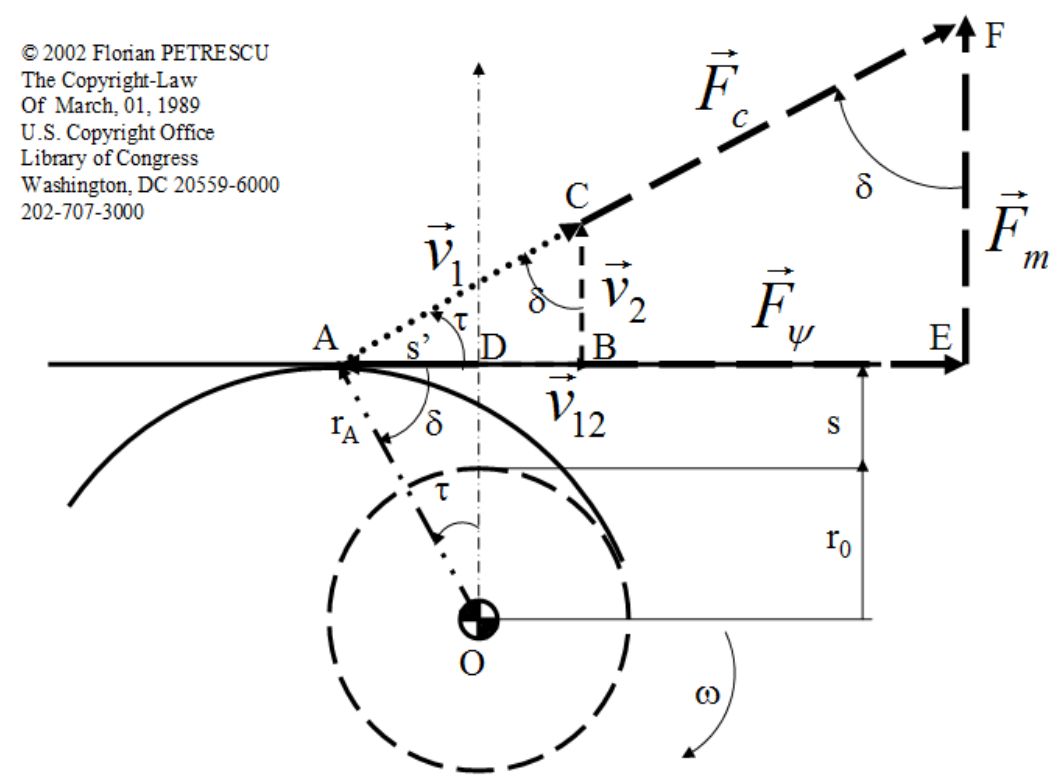

Fig. 11. Forces and speeds on the classic mechanism with cam and plane follower 
Then calculate A, B and $\omega^{2}$ with system relationships (64) and $\varepsilon$ with expression (66).

From (67-70) remove $x, x^{\prime}, x^{\prime \prime}$ and.

Where $\omega_{m}$ represents the mean nominal speed of the cam and is expressed in the distribution mechanisms according to the speed of the motor shaft (65); $\varphi_{0}=\varphi_{u}$ or $\varphi_{c}$ :

$$
\begin{aligned}
& \left\{\begin{array}{l}
\omega^{2}=\omega_{m}^{2} \cdot \frac{A}{B} \\
A=M_{c} \cdot R_{0}^{2}+M_{c} \cdot \frac{h^{2}}{8}+\frac{1}{2} \cdot M_{c} \cdot R_{0} \cdot h \\
+\frac{1}{8} \cdot M_{c} \cdot \frac{\pi^{2} \cdot h^{2}}{\phi_{0}^{2}}+\frac{1}{4} \cdot m_{T} \cdot \frac{\pi^{2} \cdot h^{2}}{\phi_{0}^{2}} \\
B=M_{c} \cdot R_{0}^{2}+M_{c} \cdot s^{2}+2 \cdot M_{c} \cdot R_{0} \cdot s+M_{c} \cdot s^{\prime 2}+2 \cdot m_{T} \cdot s^{\prime 2}
\end{array}\right. \\
& \omega_{m}=2 \cdot \pi \cdot v_{c}=2 \cdot \pi \cdot \frac{n_{c}}{60}=\frac{2 \cdot \pi}{60} \cdot \frac{n_{m o t o r}}{2}=\frac{\pi \cdot n}{60} \\
& \varepsilon=-\omega^{2} \cdot \frac{\left(M_{c} \cdot s+M_{c} \cdot R_{0}+M_{c} \cdot s^{\prime \prime}+2 \cdot m_{T} \cdot s^{\prime \prime}\right) \cdot s^{\prime}}{B}
\end{aligned}
$$

For a classic mechanism with cam and stick (no valve) the dynamic displacement of the stick is expressed with the relation (67):

$$
\begin{aligned}
& x=s \\
& -\frac{(K+k) \cdot m_{T} \cdot \omega^{2} \cdot s^{\prime 2}+\left(k^{2}+2 k \cdot K\right) \cdot s^{2}+2 k \cdot x_{0} \cdot(K+k) \cdot s}{2 \cdot(K+k)^{2} \cdot\left(s+\frac{k \cdot x_{0}}{K+k}\right)}
\end{aligned}
$$

where, $x$ represents the dynamic movement of the stick, while $s$ is its normal movement (kinematic). $K$ is the elastic constant of the system and $k$ represents the elastic constant of the spring that holds the stick. It is noted with $x_{0}$ the pretension of the stem spring, with $m_{T}$ of the tappet mass, with $\omega$ the angular velocity of the cam (or camshaft), $s^{\prime}$ being first derived according to $\varphi$ of the stroke displacement $s$. Twice, successively, The expression (67) with respect to the angle $\varphi$, obtains the reduced speed (relation 68) and the reduced throttle acceleration (69):

$$
\left\{\begin{array}{l}
N=(K+k) \cdot m_{T} \cdot \omega^{2} \cdot s^{\prime 2}+\left(k^{2}+2 k \cdot K\right) \cdot s^{2}+2 k \cdot x_{0} \cdot(K+k) \cdot s \\
M=\left[(K+k) m_{T} \omega^{2} \cdot 2 s^{\prime} s^{\prime \prime}+\left(k^{2}+2 k K\right) \cdot 2 s s^{\prime}+2 k x_{0}(K+k) \cdot s^{\prime}\right] \\
\cdot\left(s+\frac{k x_{0}}{K+k}\right)-N \cdot s^{\prime} \\
x^{\prime}=s^{\prime}-\frac{M}{2 \cdot(K+k)^{2} \cdot\left(s+\frac{k x_{0}}{K+k}\right)^{2}}
\end{array}\right.
$$

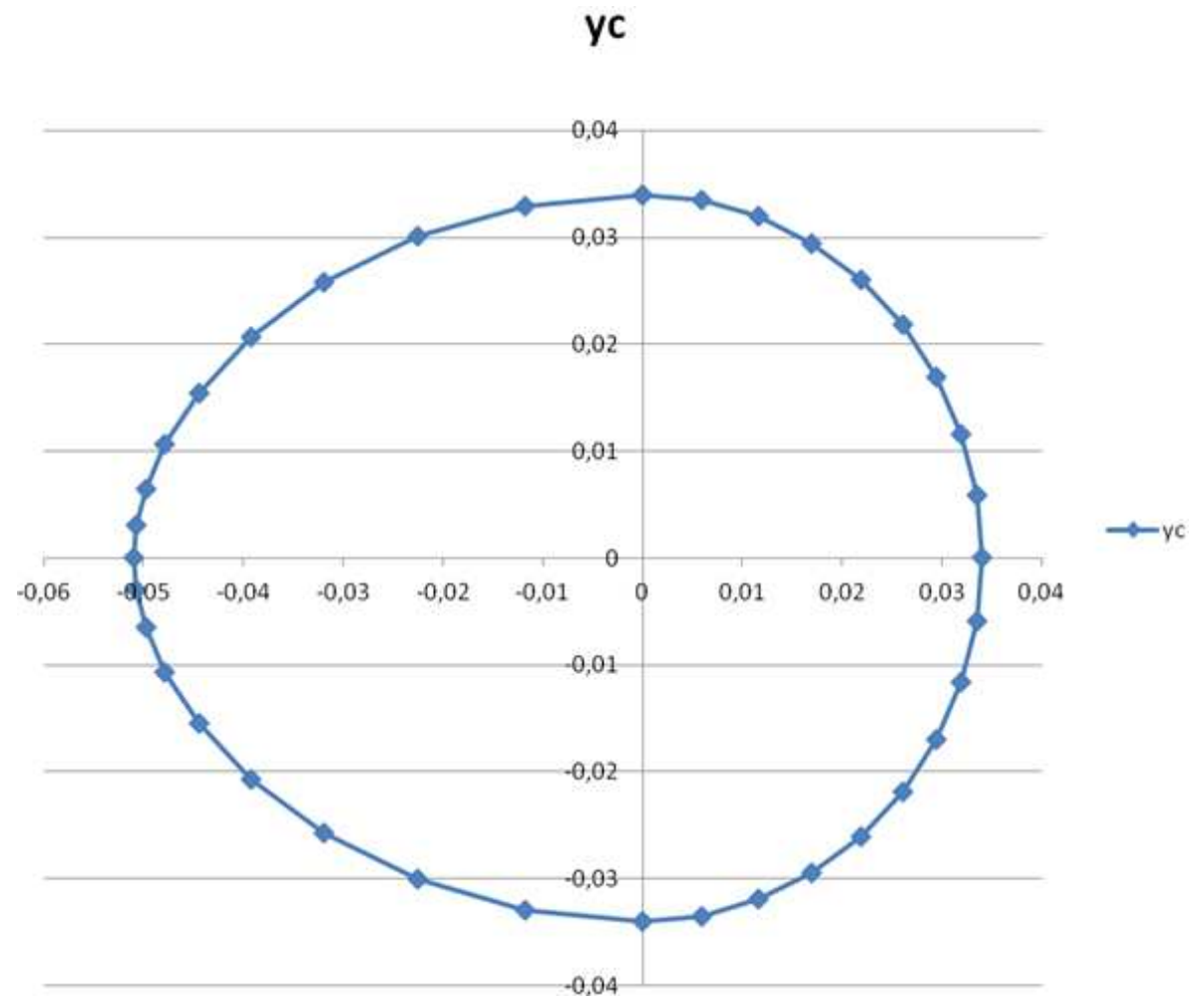

Fig. 12. The cam profile 


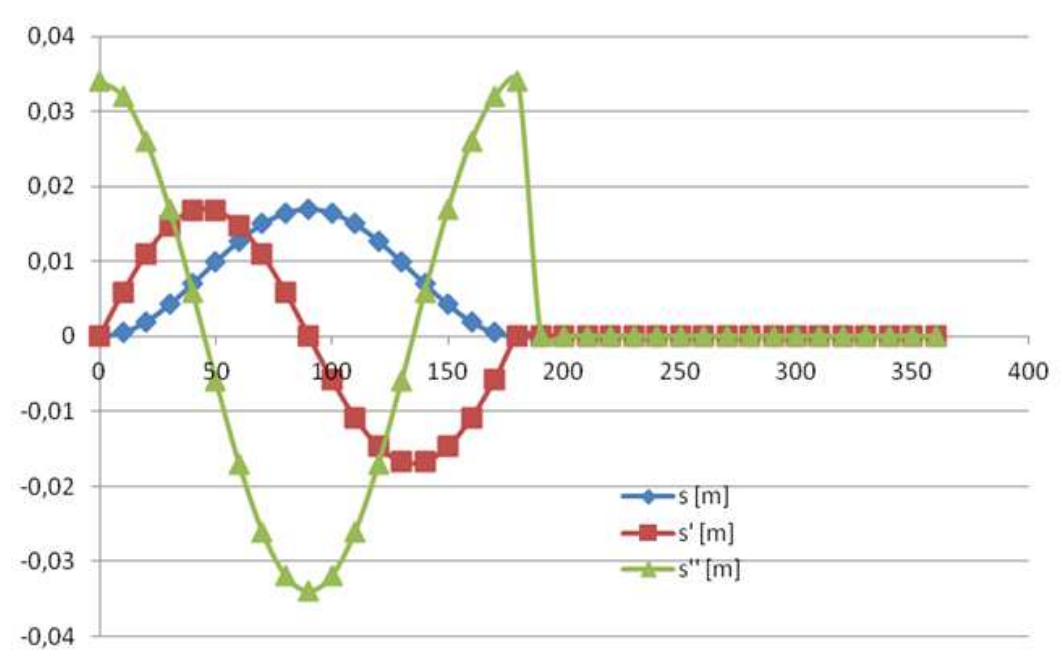

Fig. 13. The laws cos in utilized

\section{$\operatorname{xpp}[\mathrm{m} / \mathrm{s} 2]$}

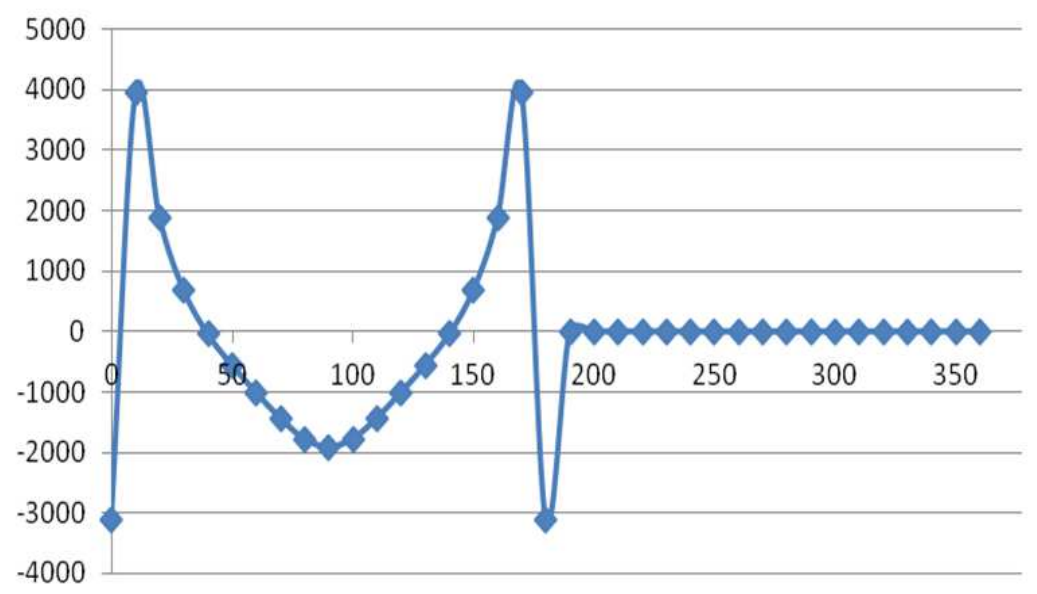

Fig. 14. The dynamic diagram of the tappet movement

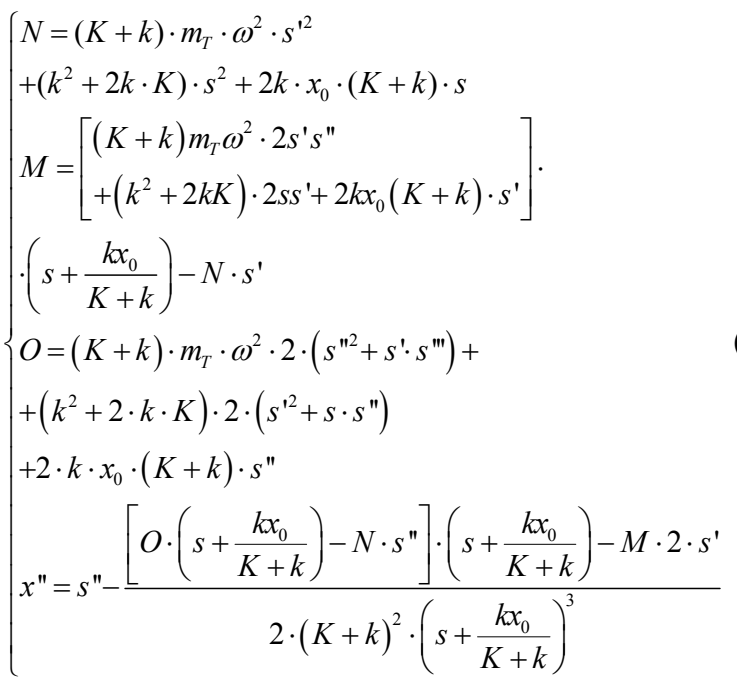

Next, the actual (dynamic) throttle acceleration can be directly determined using the relationship (70):

$\ddot{x}=x^{\prime \prime} \cdot \omega^{2}+x^{\prime} \cdot \varepsilon$

There follows dynamic analysis, where $k, x_{0}, r_{0}, h, \varphi_{u}$ and the motion laws used are changed.

In the Fig. 12 one can see the cam profile, in Fig. 13 were represented the movement laws, cosines and in Fig. 14 the dynamic diagram of the tappet movement.

\section{Discussion}

The development and diversification of machines and mechanisms with applications in all fields requires new scientific researches for the systematization and improvement of existing 
mechanical systems by creating new mechanisms adapted to modern requirements, which involve increasingly complex topological structures.

The modern industry, the practice of designing and building machinery is increasingly based on the results of scientific and applied research.

Each industrial achievement has backed theoretical and experimental computer-assisted research, which solves increasingly complex problems with advanced computing programs using increasingly specialized software.

The robotization of technological processes determines and influences the emergence of new industries, applications under special environmental conditions, the approach of new types of technological operations, manipulation of objects in the alien space, teleoperators in the top disciplines like medicine, robots covering a whole field Greater service provision in our modern, computerized society.

The paper presents an original method to determine the general dynamics of rotating cam and lifting, customized to flat-plate mechanism. First, the dynamic cinematic is presented. Then the Lagrange equation is resolved and with an original dynamic model with a degree of freedom with variable internal damping the dynamic analysis of two models is then made. The mechanisms presented, scientifically called rigid memory mechanisms, are mechanical transmissions widely used in the economy for many years. They are widespread in the medical world, being used in various medical devices and in medical engineering, they also meet most of the vehicles mounted on their engines, with internal combustion, as valve distribution mechanisms, in the world of industrial robots, but also in the of mechanical transmissions. The cam and follower mechanisms have spread the first time they were used in the wars of tissue (automated tissue machines). The distribution mechanisms could not be replaced with other electromechanical systems because they did not have the necessary resistance and reliability.

\section{Conclusion}

Using classic motion laws, the distribution mechanism dynamics quickly depreciates when increasing the rotational speed of the shaft. In order to sustain a high rotation speed, it is necessary to synthesize the cam profile with the proposed new motion laws.

\section{Acknowledgement}

This text was acknowledged and appreciated by Dr. Veturia CHIROIU Honorific member of Technical Sciences Academy of Romania (ASTR) PhD supervisor in Mechanical Engineering.

\section{Funding Information}

Research contract: Contract number 36-5-4D/1986 from 24IV1985, beneficiary CNST RO (Romanian National Center for Science and Technology) Improving dynamic mechanisms internal combustion engines. All these matters are copyrighted. Copyrights: 394qodGnhhtej from 17-02-2010 13:42:18; 421qDiazjHkBu from 01-03-2010 22:49:44; $1375-$ tnzjHFAqGF from 02-09-2011 15:19:23; 3679vpqggvwrhm from 04-01-2015 01:44:46.

\section{Author's Contributions}

All the authors contributed equally to prepare, develop and carry out this manuscript.

\section{Ethics}

This article is original and contains unpublished material. Authors declare that are not ethical issues and no conflict of interest that may arise after the publication of this manuscript.

\section{References}

Angeles, J. and C. Lopez-Cajun, 1988. Optimal synthesis of cam mechanisms with oscillating flat-face followers. Mechanism Mach. Theory, 23: 1-6.

DOI: 10.1016/0094-114X(88)90002-X

Antonescu, P. and F. Petrescu, 1985. Metodã analiticã de sintezã a mecanismului cu camã si tachet plat. Lucrările celui de-al IV-lea Simpozion International de Teoria si Practica Mecanismelor, (TPM' 85), Bucuresti.

Antonescu, P. and F. Petrescu, 1989. Contributii la analiza cinetoelastodinamicã a mecanismelor de distributie. Bucuresti.

Antonescu, P., M. Oprean and F. Petrescu, 1985a. Contributii la sinteza mecanismului cu camã oscilantã si tachet plat oscilant. Lucrările celui de-al IV-lea Simpozion International de Teoria si Practica Mecanismelor, (TPM' 85), Bucuresti.

Antonescu, P., M. Oprean and F. Petrescu, 1985b. La projection de la came oscillante chez les mechanismes a distribution variable. Lucrările celui de-a V-a Conferintã de Motoare, Automobile, Tractoare si Masini Agricole, Vol. I-Motoare si Automobile, (AMA’ 85), Brasov.

Antonescu, P., M. Oprean and F. Petrescu, 1986. Proiectarea profilului Kurz al camei rotative ce actioneazã tachetul plat oscilant cu dezaxare. Lucrările celui de-al III-lea Siopozion National de Proiectare Asistatã de Calculator în Domeniul Mecanismelor si Organelor de Masini, (MOM' 86), Brasov. 
Antonescu, P., M. Oprean and F. Petrescu, 1987. Analiza dinamicã a mecanismelor de distributie cu came. Lucrările celui de-al VII-lea Simpozion National de Roboti Industriali si Mecanisme Spatiale, (IMS’ 87), Bucuresti.

Antonescu, P., M. Oprean and F. Petrescu, 1988. Sinteza analiticã a profilului Kurz, la cama cu tachet plat rotativ. Revista Constructia de Masini, Bucuresti.

Antonescu, P., F. Petrescu and O. Antonescu, 1994. Contributii la sinteza mecanismului cu camã rotativã si tachet balansier cu vârf. Brasov.

Antonescu, P., F. Petrescu and D. Antonescu, 1997. Geometrical synthesis of the rotary cam and balance tappet mechanism. Bucuresti.

Antonescu, P., F. Petrescu and O. Antonescu, 2000a. Contributions to the synthesis of the rotary disc-cam profile. Proceedings of the 8 th International Conference on the Theory of Machines and Mechanisms, (TMM' 00), Liberec, Czech Republic, pp: 51-56.

Antonescu, P., F. Petrescu and O. Antonescu, $2000 \mathrm{~b}$. Synthesis of the rotary cam profile with balance follower. Proceedings of the 8th Symposium on Mechanisms and Mechanical Transmissions, (MMT'00), Timişoara, pp: 39-44.

Antonescu, P., F. Petrescu and O. Antonescu, 2001. Contributions to the synthesis of mechanisms with rotary disc-cam. Proceedings of the 8th IFToMM International Symposium on Theory of Machines and Mechanisms, (TMM' 01), Bucharest, ROMANIA, pp: 31-36.

Giordana, F., V. Rognoni and G. Ruggieri, 1979. On the influence of measurement errors in the Kinematic analysis of cams. Mechanism Mach. Theory, 14: 327-340. DOI: 10.1016/0094-114X(79)90019-3

Hain, K., 1971. Optimization of a cam mechanism - to give good transmissibility, maximal output angle of swing and minimal acceleration. J. Mechan., 6: 419-434. DOI: 10.1016/0022-2569(71)90044-9

Mirsayar, M.M., V.A. Joneidi, R.V. Petrescu, F.I.T. Petrescu and F. Berto, 2017. Extended MTSN criterion for fracture analysis of soda lime glass. Eng. Fracture Mechan., 178: 50-59.

DOI: 10.1016/j.engfracmech.2017.04.018

Petrescu, F. and R. Petrescu, 1995a. Contributii la optimizarea legilor polinomiale de miscare a tachetului de la mecanismul de distributie al motoarelor cu ardere internã. Bucuresti.

Petrescu, F. and R. Petrescu, 1995b. Contributii la sinteza mecanismelor de distributie ale motoarelor cu ardere internã. Bucuresti.

Petrescu, F. and R. Petrescu, 1997a. Dinamica mecanismelor cu came (exemplificatã pe mecanismul clasic de distributie). Bucuresti.
Petrescu, F. and R. Petrescu, 1997b. Contributii la sinteza mecanismelor de distributie ale motoarelor cu ardere internã cu metoda coordonatelor carteziene. Bucuresti.

Petrescu, F. and R. Petrescu, 1997c. Contributii la maximizarea legilor polinomiale pentru cursa activã a mecanismului de distributie de la motoarele cu ardere internã. Bucuresti.

Petrescu, F. and R. Petrescu, 2000a. Sinteza mecanismelor de distributie prin metoda coordonatelor rectangulare (carteziene). Universitatea din Craiova, Craiova.

Petrescu, F. and R. Petrescu, 2000b. Designul (sinteza) mecanismelor cu came prin metoda coordonatelor polare (metoda triunghiurilor). Universitatea din Craiova, Craiova.

Petrescu, F. and R. Petrescu, 2002a. Legi de mişcare pentru mecanismele cu came. Lucrările celui de-al VII-lea Simpozion Naţional cu Participare Internaţională Proiectarea Asistată de Calculator, (PAC' 02), Braşov, pp: 321-326.

Petrescu, F. and R. Petrescu, 2002b. Elemente de dinamica mecanismelor cu came. Lucrările celui deal VII-lea Simpozion Naţional cu Participare Internaţională Proiectarea Asistată de Calculator, (PAC' 02), Braşov, pp: 327-332.

Petrescu, F. and R. Petrescu, 2003. Câteva elemente privind îmbunătăţirea designului mecanismului motor. Lucrările celui de-al VIII-lea Simpozion Naţional, de Geometrie Descriptivă, Grafică Tehnică şi Design, (GTD’ 03), Braşov, pp: 353-358.

Petrescu, F. and R. Petrescu, 2005a. The cam design for a better efficiency. Proceedings of the International Conference on Engineering Graphics and Design, (EGD’ 05), Bucharest, pp: 245-248.

Petrescu, F. and R. Petrescu, 2005b. Contributions at the dynamics of cams. Proceedings of the 9th IFToMM International Symposium on Theory of Machines and Mechanisms, (TMM' 05), Bucharest, Romania, pp: 123-128.

Petrescu, F. and R. Petrescu, 2005c. Determining the dynamic efficiency of cams. Proceedings of the 9th IFToMM International Symposium on Theory of Machines and Mechanisms, (TMM' 05), Bucharest, Romania, pp: 129-134.

Petrescu, F. and R. Petrescu, 2005d. An original internal combustion engine. Proceedings of the 9th IFToMM International Symposium on Theory of Machines and Mechanisms, (TMM' 05), Bucharest, Romania, pp: $135-140$.

Petrescu, F. and R. Petrescu, 2005e. Determining the mechanical efficiency of Otto engine's mechanism. Proceedings of the 9th IFToMM International Symposium on Theory of Machines and Mechanisms, (TMM' 05), Bucharest, Romania, pp: 141-146. 
Petrescu, F., R. Petrescu and O. Antonescu, 2002a. Randamentul cuplei superioare de la angrenajele cu roţi dinţate cu axe fixe. Lucrările celui de-al VII-lea Simpozion Naţional cu Participare Internaţională Proiectarea Asistată de Calculator, (PAC' 02), Braşov, pp: 333-338.

Petrescu, F., R. Petrescu and C. Ocnarescu, 2002b. The cam synthesis with maximal efficiency. Lucrările celui de-al VII-lea Simpozion Naţional cu Participare Internaţională Proiectarea Asistată de Calculator, (PAC' 02), Braşov, pp: 339-344.

Petrescu, F., R. Petrescu and N. Popescu, 2005. The efficiency of cams. Proceedings of the 2nd International Conference "Mechanics and Machine Elements", Nov. 4-6, Technical University of Sofia, Sofia, Bulgaria, pp: 237-243.

Petrescu, F.I., 2008 Contribuţii teoretice şi aplicative privind dinamica mecanismelor plane cu cuple superioare. Teza de Doctorat.
Taraza, D., N.A. Henein and W. Bryzik, 2001. The frequency analysis of the crankshaft's speed variation: A reliable tool for diesel engine diagnosis. ASME J. Gas Turbines Power, 123: 428-432. DOI: $10.1115 / 1.1359479$

Taraza, D., 2002. Accuracy limits of IMEP determination from crankshaft speed measurements. SAE Trans. J. Engines, 111: 689-697. DOI: $10.4271 / 2002-01-0331$

Taraza, D., 2003a. Statistical correlation between the crankshaft's speed variation and engine performance, Part I: Theoretical model. ASME J. Eng. Gas Turbines Power, 125: 791-796. DOI: 10.1115/1.1563244

Taraza, D., 2003b. Statistical correlation between the crankshaft's speed variation and engine performance, Part II: Detection of deficient cylinders and MIP calculation. ASME J. Eng. Gas Turbines Power, 125: 797-803.

DOI: $10.1115 / 1.1563245$ 